\title{
Subsurface Layers Modeling and Ground Water Studies in Kivi Plain by Geoelectric
}

Behnam Taghavi*, Farnusch Hajizadeh and Rana Khaleghi

Department of Mining Engineering, Urmia University, West Azerbaijan, Urmia, Iran

*Corresponding author: Behnam T, MSc Student, Urmia University, West Azerbaijan, Urmia, Iran, Tel: +233030701001; E-mail: b.taghavi69@gmail.com

Rec date: Mar 31, 2016; Acc date: July 15, 2016; Pub date: July 25, 2016

Copyright: @ 2016 Taghavi B, et al. This is an open-access article distributed under the terms of the Creative Commons Attribution License, which permits unrestricted use, distribution, and reproduction in any medium, provided the original author and source are credited.

\begin{abstract}
Kivi Plainis located in the northeastern city of Kiviin Ardabil province. Due to the large number of villages in the desert and its people engaged in agriculture and animal husbandry, Study of ground water to determination of the optimal location of wells is important. In this regard, geoelectric technique was used for studies of groundwater quality and quantity of Kivi plain.

In this research, the resolution of the subsurface layers, detection of saturated zone, determination of basement, detection of the general direction of groundwater and changes of resistivity in sounding points and profiles have been studied.

The number of 196 vertical electrical sounding on nine profiles and the number of 9 sounding in variety points and in vicinity of exploratory wells by schlumberger array in the study area have been taken. "IPI2win" software is used for the interpretation of vertical electrical sounding curves and one-dimensional modeling. By "Res2dinv", twodimensional modeling and preparation of resistivity section have been taken. According to the results of the interpretation of the data in the study area, sediments inparts of the Middle East and Northern have developed, and from the surface to the depth of alluvium and marl deposits were included. More aquifer layers in marly sand deposits, silt and sand, crushed limestone and salty zones were observed. Basement is included most of marl (with the layers of sandstone and conglomerate), limestone and silt. According to the basement, the topography slope of the area and isopiezecurves, groundwater movement is toward the northeast.
\end{abstract}

Keywords: Vertical electrical sounding; Aquifer layers; Resistivity

\section{Introduction}

Water is essential for development of different seasons irrigation, industry and domestic purpose. Groundwater is the main source for potable water supply, domestic, industrial and agricultural uses. The scarcity of groundwater increases day by day due to rapid population, urbanization, industrial and agricultural related activities, failure of monsoon natural calamities. Groundwater is more advantageous than the surface water due to its lesser extent of evaporation. Water scarcity problem affects the human chain and other living things. To meet out the demand of water, people are depending more on aquifers. There are two end members in spectrum of types of aquifers; confined and unconfined (with semi confined aquifer being in between them) [1]. The study area is covered by sedimentary and hard rock formations, and faces acute water scarcity problem both with respect to irrigation as well as drinking purposes [2]. Occurrence of groundwater in this type of area is limited to fractured and weathered horizons and upper unconsolidated materials. For identifying the groundwater potential in the hard rock terrain, the main target is fractured zone [3]. The concept of integrated Remote sensing and GIS has proved to be an efficient tool in groundwater studies and the inclusion of subsurface information inferred from geoelectrical survey can give more realistic picture of groundwater potential of an area [4-6]. Surface electrical resistivity surveys were conducted at different locations to obtain subsurface lithological information, identification of horizontal and vertical disposition of aquifer system [7]. The rapid rural development in and around the study area and the associated activities have resulted in the increase of population demands leading so excesses utilization of groundwater. Because of the over exploitation of groundwater, the groundwater level has been declined in recent times [8]. Warrants groundwater assessment for sustainable utilization within the study area. The main objective of the investigation is to delineate the subsurface lithology and to assess the groundwater resources of the sub watershed. It's also aim to focus on the identification of fracture zone and its thickness by using VES (Vertical Electrical Sounding) method $[9,10]$. The exploration of buried underground resources, cannot be rely on geological information have to inevitably somehow the works of designing of these resources appear on the ground. However, the use of geophysics for both groundwater resource mapping and for water quality evaluations has increased dramatically over the last 10 years in large part due to the rapid advances in microprocessors and associated numerical modeling solutions. The vertical electrical sounding (VES) by schlumberger array has proved very popular with groundwater studies due to simplicity of the technique. Traditional methods for characterizing protective layers include test hole drilling and analyses of log, with the objective being to characterize thickness and/or lateral extent of the protective layer $[11,12]$.

\section{Location and Geology of the Study Area}

The study area considered is Kivi Plain is which is located in the northeastern city of Kiviin Ardabil province. It lies between the longitudes of $47^{\circ} 32^{\prime} 6^{\prime \prime}$ to $47^{\circ} 51^{\prime} 3^{\prime \prime} \mathrm{E}$ and latitudes of $35^{\circ} 49^{\prime} 23^{\prime \prime}$ to $36^{\circ} 00^{\prime} 36^{\prime \prime}$ $\mathrm{N}$ (Figure 1). 


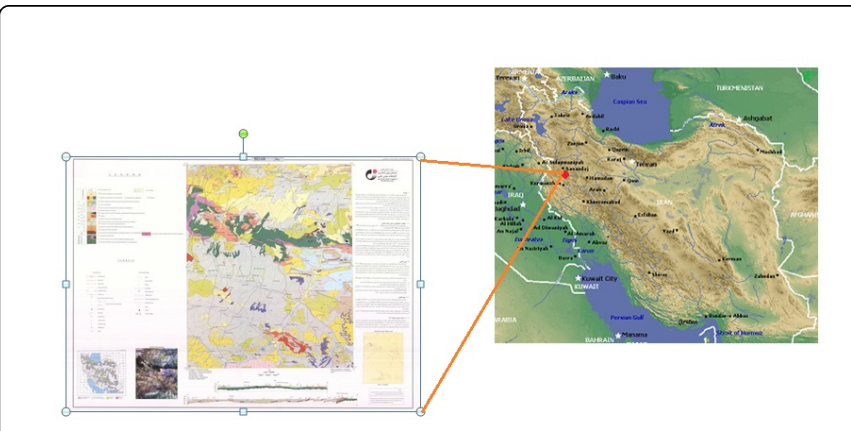

Figure 1: Location map of the Study area.

Due to the large number of villages in the desert and its people engaged in agriculture and animal husbandry, Study of ground water to determination of the optimal location of wells is important.

From the view point of geology and structural geology, Kivi Plainis is located in sanandaj- sirjan zone. In this zone, sediments of older than cretaceous are absent, Approximately entire area has been covered by Slats mainly green as upper Cretaceous age and partly, Mocene too. In west part of watershed were observed intermediate of Andesite and sandy shale. The study area, sediments inparts of the Middle East and Northern have developed, and from the surface to the depth of alluvium and marl deposits were included. More aquifer layers in marly sand deposits, silt and sand, crushed limestone and salty zones were observed. Groundwater occurs under water table conditions in the joints, fractures and weathered rocks. Generally, study area fractures occured in NE-SW direction in southwest and NW-SE direction in south, which in turn result in rich potential (Figure 2).

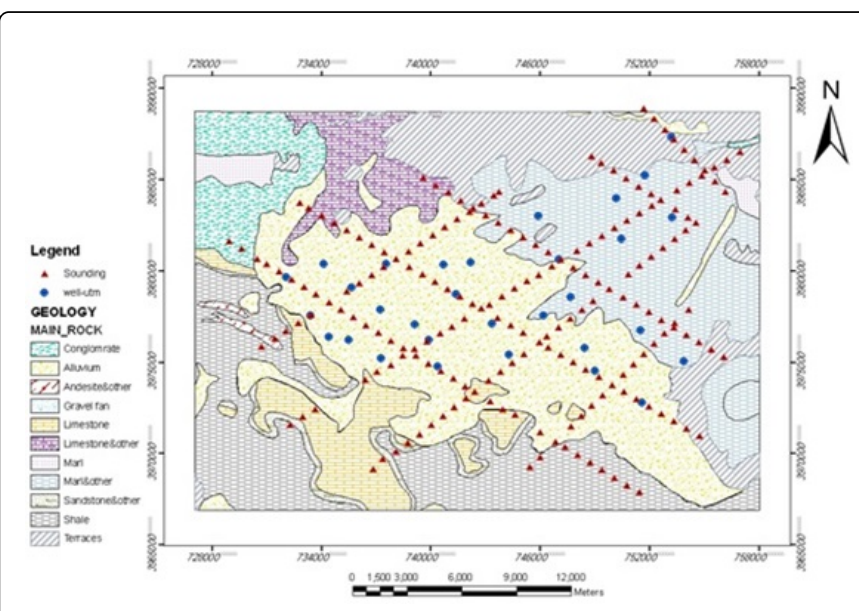

Figure 2: Geology Map of study area and location of sounding and wells.

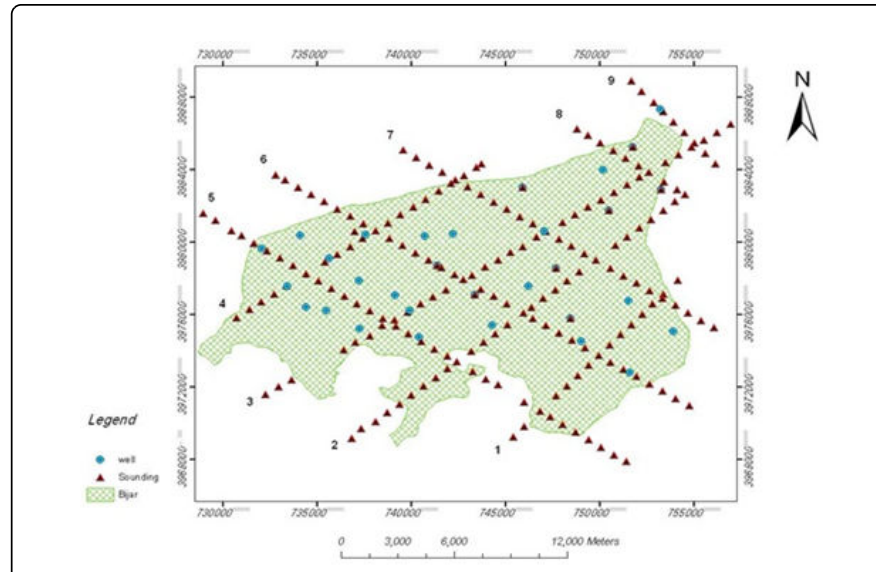

Figure 3: The location of electrical profiles and soundings in the study area.

\section{Geoelectrical Resistivity Survey}

According to Figure 3, The number of 196 vertical electrical sounding on 9 profiles and the number of 9 sounding in variety points and in vicinity of exploratory wells by schlumberger array in the study area have been taken. That sounding spacing was $800 \mathrm{~m}$ with maximum electrode separation $(\mathrm{AB} / 2), 400 \mathrm{~m}$ in successive steps. Direction of total profiles was NW-SE and NE-SW. The 3 nos. of sounding in profile. 3 have unregistered by contact with municipal utilities.

"IPI2win" software is used for the interpretation of vertical electrical sounding curves and one-dimensional modeling. By "Res2dinv", twodimensional modeling and preparation of resistivity section have been taken. The Arc GIS software is used to prepare The Geology maps, location of electrical profiles and soundings. By using Surfer, resistivity contour maps have been generated for different depth ranges to identify and demarcate the anomaly zones by $3 \mathrm{D}$ modeling of bed rock.

\section{Results and Discussion}

Collected soundings data are interpreted by two layers curves fitting method and using geological information. After recognizing layers and related resistivities along each sounding, pseudo $2 \mathrm{D}$ resistivity sections are plotted and then using geological information and drilling logs subsurface structures are delinated. Then to optimize the results, $2 \mathrm{D}$ invesion are used to invert measured appearent resistivities to real resistivities. By interpreting $2 \mathrm{D}$ geoelectric sections from the inversion, study of geological structures, estimating thickness of alluvial, Hydrology, delineating fractures and faults, position and material of rock and determining location of wells.

According to Figure 4, The first and second layers were included alluvium deposits with the layers of silty. The lower resistivity in the next parts is due to finer materials of silt and clay. However the fourth geoelectric layer could be said to compose of marly sand. It had a resistivity in Approximately $55 \Omega \mathrm{m}$. The average resistivity of saturated aquifer were calculated in the study basin as $10 \Omega \mathrm{m}$ in $30 \mathrm{~m}$ of Depth. Then, the sounding curves were interpreted to determine the true resistivities and thicknesses of the subsurface layers. 

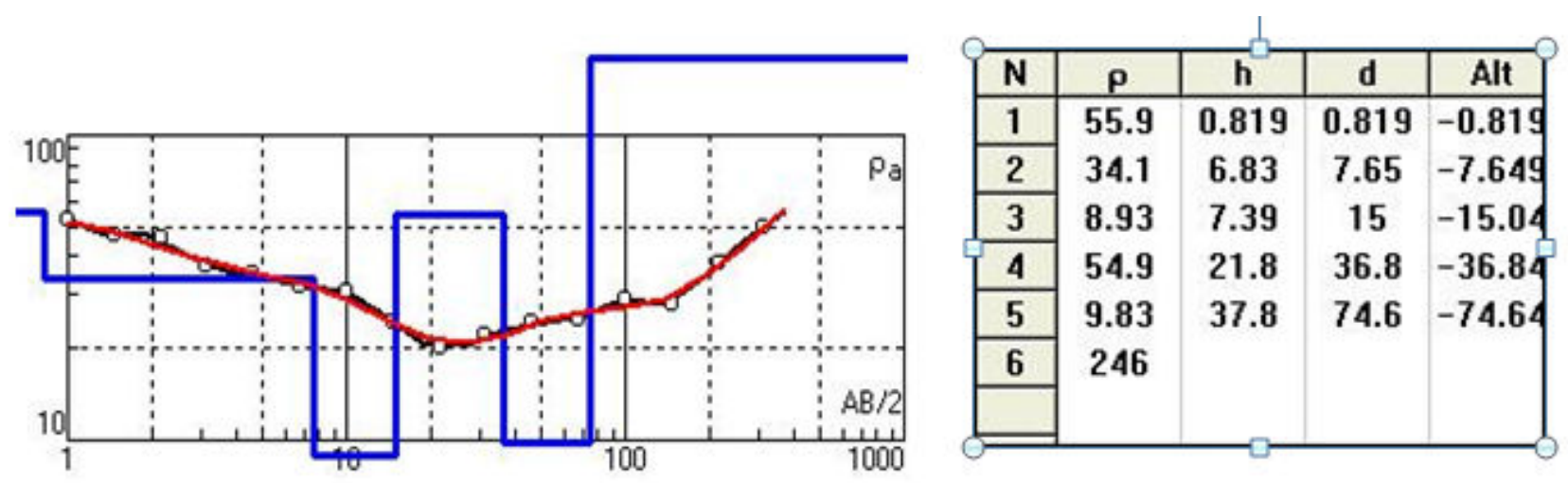

Figure 4: Interpretations of VES Field Curves (sounding P2).

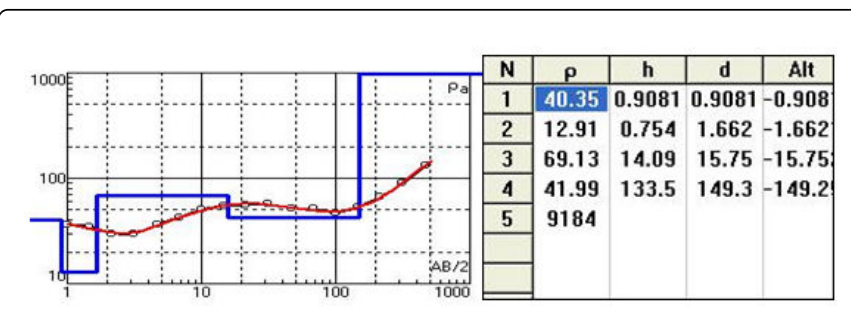

Figure 5: Interpretations of VES Field Curves (sounding 170).

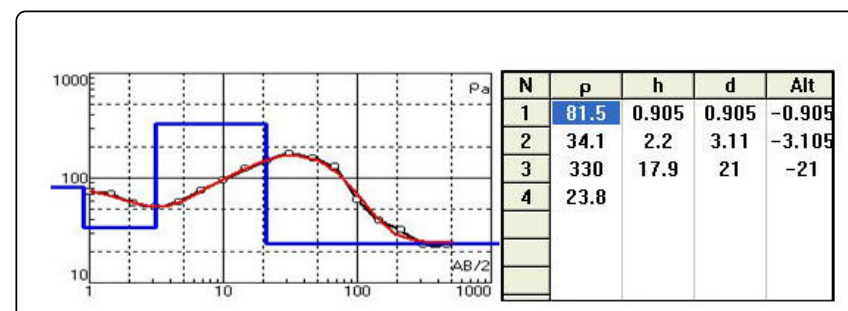

Figure 6: Interpretations of VES Field Curves (sounding 4).

Figure 5 shows that the topsoil had included of silty alluvium deposits with thickness range of $1.00 \mathrm{~m}$ to $1.9 \mathrm{~m}$. The higher resistivity in the third geoelectric layer is due to marly and conglomerate deposits. The forth layer had resistivity to $42 \Omega \mathrm{m}$ and is probable of saturated aquifer in marly formation.

Average resistivity of the surface layer calculated in the range $82 \Omega \mathrm{m}$ (Figure 6). The decrease of resistivity is indicative from silt-sand alluvium deposits. The higher resistivity $[330 \Omega \mathrm{m}]$ in depth of $3 \mathrm{~m}$ may be due to the presence of sand or gravel.

According to Figures 7 and 8, VES success must rely on the careful interpretation and integration of the results with the other geologic and hydrogeologic data for the site. Therefore, litologic information obtained from log could be used to calibrate the VES field curves. Where test hole-log information was available, the solution to automatic interpretation procedure was constrained by keeping know layer thickness constant during the program computations. In final, the results of the Schlumberger electrical soundings have been compared with the geological sections have been obtained from the dug wells. These results are in a good agreement with the geological sections. Figure 9 shows, 28 vertical electrical soundings by Schlumberger array were conducted out at this profile. which trends of total profile approximately was NE-SW, with a length of $22400 \mathrm{~m}$.

The minimum and maximum apparent resistivity calculated in the pseudo sections are respectively as $5 \Omega \mathrm{m}, 800 \Omega \mathrm{m}$ and all the VES are multilayered geoelectrical sections. The Geoelectrical sections of the study area shows the real resistivity in the range of $>5 \Omega \mathrm{m}$ to $3000 \Omega \mathrm{m}$.

The inversion model in shown in Figure 10. The thickness of the lower resistivity weathered layer is generally about 10 to 20 meters. There is a narrow vertical low resistivity zone between the soundings 2-3 and soundings 5-6 that is probably a fracture zone or fault in the bedrock.

The Iso resistivity maps are the resistivity contour maps and Iso is a Greek word meaning 'equal' and contours are imaginary lines on map connecting equal value. Figure 11 shows Iso-Resistivity map to be obtained from geoelectrical survey in the study area. The contour maps can be generated using Surfer 8 software packages.

Figure 12, the map also shows that the bedrock is generally lower in the southwestern part of study area, and gets Progressive reduction towards the northern region. Basement is included most of marl (with the layers of sandstone and conglomerate), limestone and silt. According to the basement, the topography slope of the area and isopiezecurves, groundwater movement is toward the northeast. Results obtained from this study gave a good picture of the basement topography as well as the groundwater potential of the area. 
Citation: Taghavi B, Hajizadeh F, Khaleghi R (2016) Subsurface Layers Modeling and Ground Water Studies in Kivi Plain by Geoelectric. Hydrol

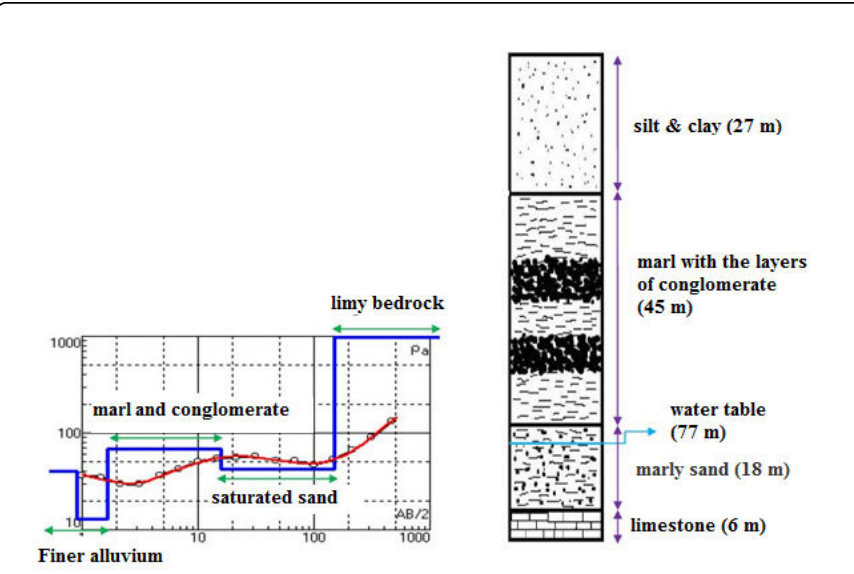

Figure 7: Compare of VES (sounding 170) with the geological sections.

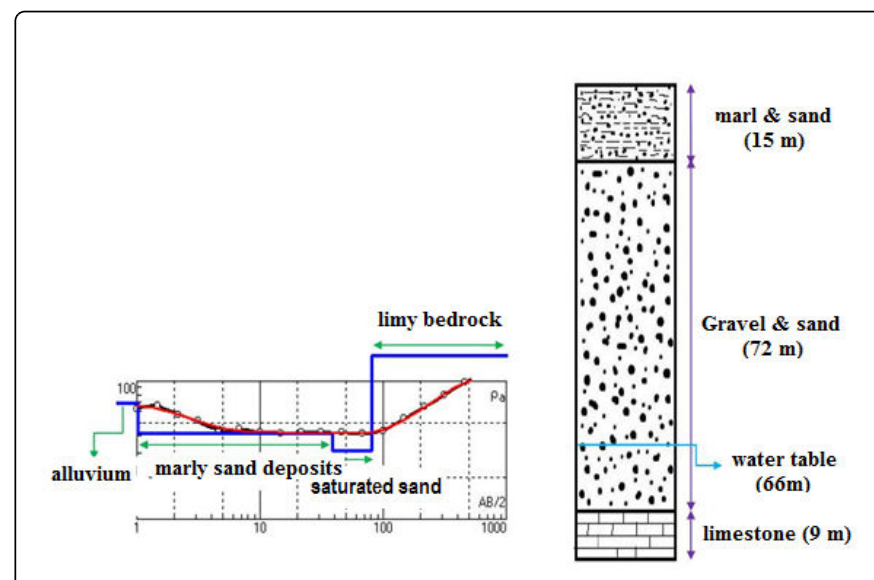

Figure 8: Compare of VES (sounding 34) with the geological sections.

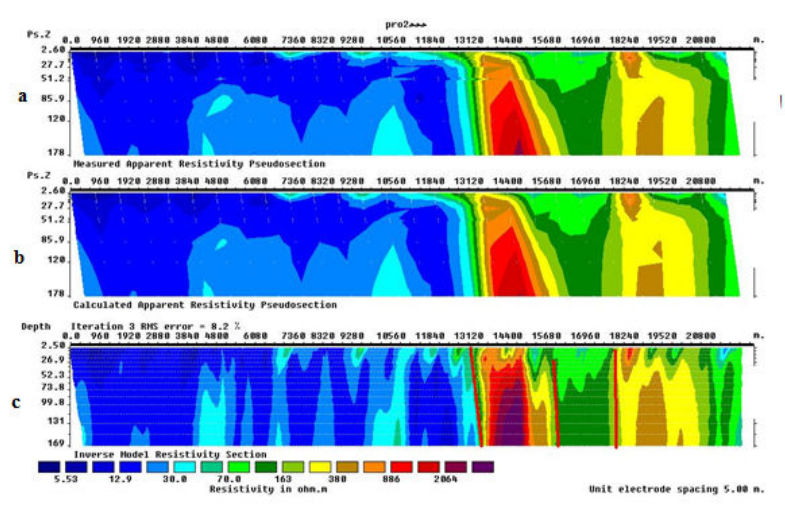

Figure 9: Resistivity pseudo section (a \& b) and Resistivity(c) of Profile2.

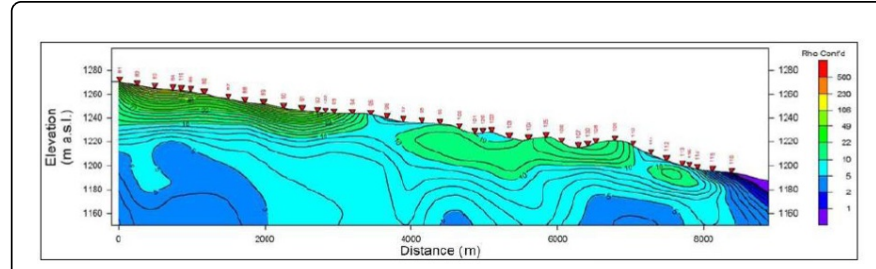

Figure 10: Map showing trends of bedrock in the study area.

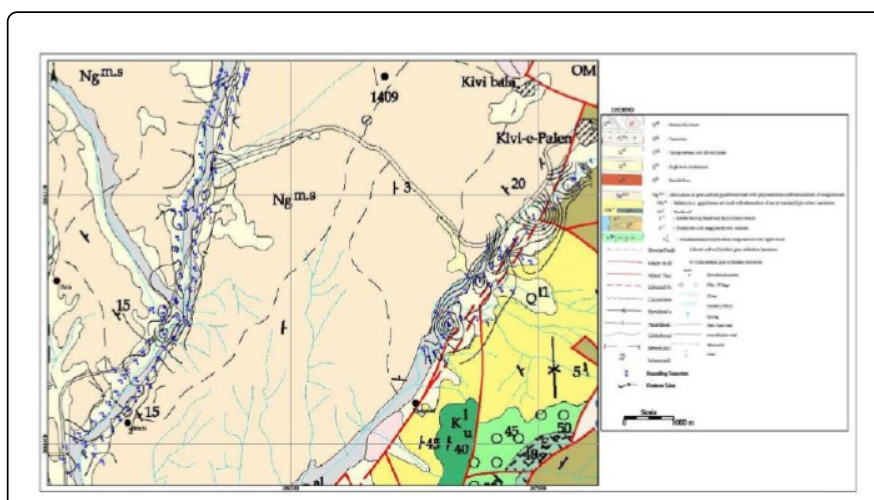

Figure 11: Study of Area.

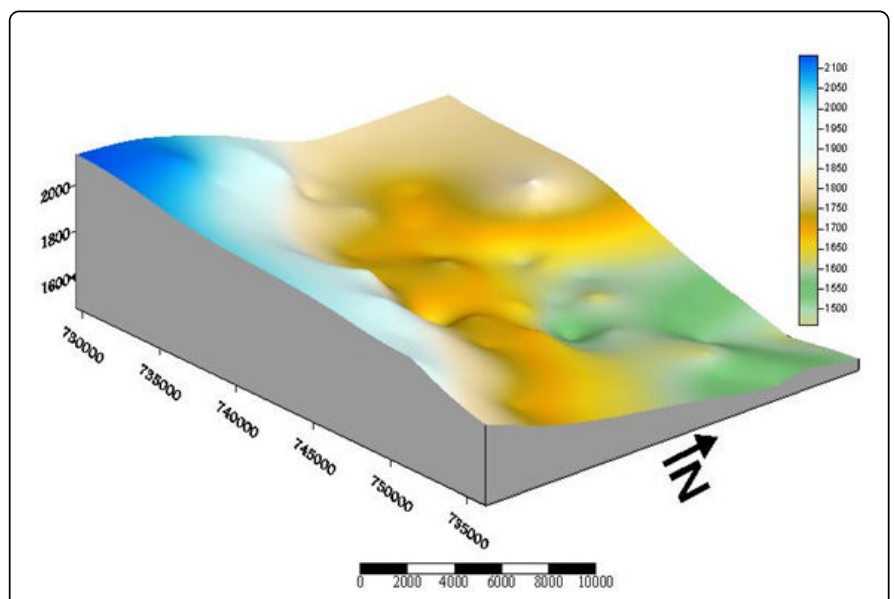

Figure 12: Map showing trends of bedrock in the study area.

\section{Conclusions}

According to the results of the interpretation of the data in the study area, sediments inparts of the Middle East and Northern have developed, and from the surface to the depth of alluvium and marl deposits were included. The maximum and minimum resistivity of study area calculated in the limestone-silty zones (300 to $10000 \Omega \mathrm{m}$ ) and marly deposits (5 to $70 \Omega \mathrm{m}$ ) respectively. More aquifer layers in marshy sand deposits, silt and sand, crushed limestone and silty zones were observed. The resistivity of the saturated aquifer decreasing towards the south due to increasing layers of marly sand, silt and sand $(<40 \Omega \mathrm{m})$. The result shows that the crushed limestone and slit zones covered by ground waters had resistivity value ranging from 100 to 200 $\Omega \mathrm{m}$ (soundings 139, 194 and 195). 
Citation: Taghavi B, Hajizadeh F, Khaleghi R (2016) Subsurface Layers Modeling and Ground Water Studies in Kivi Plain by Geoelectric. Hydrol Current Res 7: 252. doi:10.4172/2157-7587.1000252

Page 5 of 5

Interpretation of the VESs indicates the presence of an Basement is included most of marl (with the layers of sandstone and conglomerate), limestone and slate. According to the basement, the topography slope of the area and isopiezecurves, groundwater movement is toward the northeast. The boundary of the aquifer has been estimated and zones with high yield potential have been determined for future development in the basin and for choosing the drilling sites (soundings 174 to 183 ).

\section{Acknowledgements}

Professor Farnoosh Hajizadeh deserves my heartfelt thanks, without whose eye-opening comments, I would be left in confusion. Mr. Mohammed Bagher Bidad also offered guidance and support. My special feelings of gratitude go to them, whose words of encouragement and push for tenacity still ring in my ears. The authors have finally thanked of the Regional Water Board of Ardabil province to provide reports and data used in this study.

\section{References}

1. Akaolisa C (2006) Aquifer transmissivity and basement structure determination using resistivity sounding at Jos Plateau state Nigeria. Environmental monitoring and assessment, 114: 1-3.

2. Bello AA, Makinde V (2007) Delineation of the Aquifer in the SouthWestern Part of the Nupe Basin, Kwara State, Nigeria. Journal of American Science 2: 36-44.
3. El-Waheidi MM, Merlanti F, Pavan M (1992) Geoelectrical resistivity survey of the central part of Azraq basin (Jordan) for identifying saltwater/freshwater interface. Journal of Applied geophysics 29: 125-133.

4. Emenike EA (2000) Geophysical Exploration for Groundwaterin a Sedimentary Environment: A Case Study from Nanka Over Nanka Formation in Anambra Basin, Southeastern Nigeria. Global Journal of Pure and Applied Sciences 1: 97-10.

5. Heiln CA (1940) Geophysical exploration. Prentice Hall, New York, USA.

6. Ismai MI (2005) Electric resistivity investigation at Nuweiba Harbour Gulf of Aqaba, South Sinal, Egypt. Egyptian Journal of aquatic research 31: 1110-0354

7. Kelly WE, Stanislav M (1993) Applied geophysics in hydro geological and engineering practice. Elsevier, Amesterdam.

8. Kelly WE (1976) Geoelectric sounding for delineating ground water contamination. Ground Water 14: 6-11.

9. Omosuyi GO, Adeyemo A, Adegoke AO (2007) Investigation of Groundwater Prospect Using Electromagnetic and Geoelectric Sounding at Afunbiowo, near Akure, Southwestern Nigeria. The pacific Journal of Science and Technology 8: 172-182.

10. Oseiji JO, Askhia MB, Okolie (2006) Determination of groundwater potential in obiaruku and environs using surface geoelectric sounding. Environmentalist, 26: 301-308.

11. Park Y, Doh S, Yun S (2007) Geoelectric resistivity sounding of riverside alluvial aquifer in an agricultural area at Buyeo, Geum river watershed, Korea: an application to groundwater contamination study. Environmental Geology Journal 53: 849-859.

12. Zohdy AAR (1989) A new method for the automatic interpretation of Schlumberger and Wennersounding Curves. Geophysics 54: 245-253. 